\title{
Pragmatic Analysis of Presidential Campaign Manifestos of Muhammadu Buhari and Donald Trump
}

\author{
Chioma Juliet Ikechukwu-Ibe \\ Department of Linguistics, Igbo and Other Nigerian Languages, University of Nigeria Nsukka, Nigeria \\ Sopuruchi Christian Aboh \\ Department of Linguistics, Igbo and Other Nigerian Languages, University of Nigeria Nsukka, Nigeria \\ Christopher Uchenna Agbedo \\ Department of Linguistics, Igbo and Other Nigerian Languages, University of Nigeria Nsukka, Nigeria
}

\begin{abstract}
The study examines the presidential campaign manifestos of Presidents Muhammadu Buhari of the Federal Republic of Nigeria in 2015 and Donald Trump of the United States of America in 2016. Specifically, it sets out to analyse these presidents' campaign speech promises on security using the cooperative principle, ascertain the conformity of their promises on job creation to the theory of cooperative principle. The study also sets out to examine the two presidents' campaign promises on health care using the theory of cooperative principle. Using the secondary source as method of data collection, the analysis is based on one of the tenets of the Gricean (1975) Cooperative Principle- maxim of quality. The study, therefore, adopts Paul Grice's (1975) Cooperative Principle (CP) as its theoretical framework. The findings of the study suggest that both Presidents Muhammadu Buhari and Donald Trump observed the conversational maxim of quality at some point in their presidential campaign speech promises on security, job creation and health care, but violated it at some other point. In all, the maxim of quality as a conversational rule was not fairly observed by both presidents in their presidential campaign manifestos in 2015 and 2016 respectively.
\end{abstract}

Index Terms - cooperative principle, Muhammadu Buhari, Donald Trump, political campaign, maxim, manifesto

\section{INTRODUCTION}

In most organised societies, there is need for one who will be recognised as the leader. Becoming a leader in such a gathering takes due processes, one of which is political campaign (www.openelectiondata.net). Political campaigns in the opinion of Ike-Nwafor (2015) are the means by which candidates and political parties prepare and present their ideas and positions on issues to the voters in the period proceeding election day. It is, therefore, an organised effort which seeks to influence the decision making process within a specific group.

Delivering speech during political campaigns is an interesting part of the entire campaign exercise as it involves the use of well-structured and constructed linguistic items to convince the electorates. Campaign speeches are series of talks given during the official declaration of intention to run for a political position, which are capable of exciting and motivating the electorates. Donella (2010), in an attempt to define campaign speech, looks at it as having meaning only as emotional triggers. This, Donella (2010) says, is based on the claim that words are misapplied out rightly in campaign speeches to hide truths. In the opinion of Addy and Ofori (2020), campaign speeches are strategically crafted to convince the electorate of various policies, programs, and ideas. Through the speeches, politicians surreptitiously influence and control how their audience receive and perceive the information being given to them (Addy \& Ofori, 2020, p.1279).

Like other speech acts, campaign speeches are meant to be governed by some principles or rules to facilitate communication, which is the ultimate goal of every conversation. When campaign speeches are delivered, one notices elements of digression on the part of the speaker (election candidate) or misunderstanding among the listeners (electorates). While digression could stem from the speaker giving out contributions that are more or less than required at the point of delivery, misunderstanding could arise from untrue information. It is expected that while electioneerers are delivering their campaign speeches, they should not only give out adequate information or speak on relevant issues, but also speak on subjects they have observable evidences or proofs.

\section{A. Campaign Speech Message}

The message of any political campaign contains the ideas that the candidates want to share with the voters (en. wikipedia.org). It is to get those who agree with their ideas to support them when running for political positions. The 
message often consists of several talking points about policy issues with well-constructed language. The points summarise the main ideas of the campaign and are repeated frequently in order to create a lasting impression with the voters. In many elections, the opposition party will try to get the candidate off point by bringing up policy or personal questions that are not related to the talking points (en. wikipedia.org). Most campaigns prefer to keep the message broad in order to attract the most potential voters. Addy and Ofori (2020) aver that the main intention behind a political message is to legitimise a political position believed to be more credible than the other. For example, in the 2008 American presidential election, John McCain originally used a message that focused on his patriotism and political experience: 'Country First'; later the message was changed to shift attention to his role as 'The Original Maverick' within the political establishment. Barack Obama ran on a consistent, simple message of 'Change' throughout his campaign (Lyons, 2008). Like Barrack Obama, the current president of Nigeria, President Muhammadu Buhari, during his presidential campaign in 2015, used the message of 'Change'. Therefore, a well crafted or refined political campaign message may increase a candidate's changes of winning an election.

It has been observed that most times, some election candidates fail to effectively communicate their programmes to the electorates, probably, as a result of noncompliance to some conversational rules or maxims. Therefore, finding out if Presidents Muhammadu Buhari and Donald Trump have observed the maxim of quality in their presidential campaign speech manifestos, forms a problem for the study. By examining the two Presidents' presidential campaign speech manifestos of 2015 and 2016 respectively, the study wishes to establish a linguistic point of intersection between the Federal Republic of Nigeria as an underdeveloped country practicing democracy and the United States of America as a developed country also practicing democracy.

This research has, as its main purpose, to comparatively analyse the presidential campaign manifestos of Muhammadu Buhari and Donald Trump. Specifically, the study sets out to analyse Presidents Muhammadu Buhari and Donald Trump's presidential campaign speech promises on security using the cooperative principle (maxim of quality); ascertain the conformity of the two Presidents' campaign speech promises on job creation to the maxim of quality; and examine their presidential campaign speech promises on health care using the cooperative principle (maxim of quality). The maxim of quality seeks to find out how true a contribution is, and that is why it requires a speaker to contribute that which he/she can prove to be true (Grice, 1975).

\section{B. On Presidents Muhammadu Buhari and Donald Trump}

President Muhammadu Buhari, who had unsuccessfully run for the office of president of Nigeria in the 2003, 2007 and 2011 general elections, emerged the presidential candidate of the All Progressive Congress (APC) in December 2014 for the March 2015 general elections (https:/www.360dopes.com). APC as a political party is known for the slogan 'change' since it believes that the People's Democratic Party (PDP) government had performed poorly over the years. Buhari's presidential manifesto was therefore, based on the message of 'change'. Buhari came out victoriously in the election, thereby defeating the incumbent President Goodluck Jonathan. Buhari's triumph seemed to be the first time in the history of Nigeria an incumbent president lost to an opposition candidate in general elections. Currently, President Muhammadu Buhari is the 16th president of the Federal Republic of Nigeria.

President Donald Trump was a member of the Reform Party from 1999-2001; a member of the Democratic Party from 2001-2009 and also a member of the Independent Party from 2009-2011 (www.wes-weasley.fandom.com). In 2012, he joined the Republican Political Party. He entered the 2016 presidential race as a Republican and defeated sixteen opponents in the primaries. His political positions are described as populist, protectionist, and nationalist. Trump's campaign received extensive free media coverage; many of his public statements were controversial. Trump was elected president against Hillary Clinton of the Democratic Party; his victory upsets the expectations of the results of polls and analysts. Donald Trump became the oldest and wealthiest person ever to assume the presidency in the United States of America without prior military or government service. Currently, President Donald Trump is the $45^{\text {th }}$ president of the United States of America.

\section{REVIEW OF RELATED LITERATURE}

Political speeches, especially campaign speeches analysable with cooperative principle, critical discourse analysis and other linguistic theories have received considerable scholarly interests from linguists across the globe. In a study conducted by Miriti and Christopher (2016) on the use of figurative language (FL) in selected politicians' electoral campaign speeches in Meru County during 2013 Kenya general elections, figurative language was presented as mainly socio-culturally constructed and a major area for misinterpretation or manipulation when it collides within the sphere of national politics. The objectives that guided the research are to find out the categories of FL used by the politicians, examine the functions of FL, establish the relation between gender and FL; and determine the influence of politicians' educational level on the use of FL. Miriti and Christopher's (2016) study adopted Fairclough's (1998) approach to CDA and Thematic analysis as its theoretical framework. The results showed that metaphors and symbolism were the most used figures of speech by politicians, FL was used to criticise opponents, persuade electorates, make shorter versions of their ideas and boast how best fitted they were for the position. Politicians also employed figures of speech to mislead or deceive the electorate, create unity between the politicians and the electorates, illustrate the policies they had in mind for the people. Most of the politicians who used figures of speech were holders of bachelor's degree as the highest 
educational levels; politicians with highest and lowest educational levels were unlikely to employ FL in their electoral campaign speeches.

The study observed that Kenyan politics are tribal since FL along tribal lines was used to encourage voters to vote. Miriti and Christopher (2016) noted also that FL was used to divide, rule, and insult the opponents; the youth are marginalised in politics; Meru community is still a patriarchal society; the most learned were confident, careful and selective in their use of figurative language. Similarly, Waya (2017) conducted a study of the patterns of hate speeches during the Nigeria 2015 and the United States of America 2016 presidential campaigns using Van Dijk's (2004) model of Critical Discourse Analysis (CDA). The study set to compare and examine the features of the hate speeches used during the 2015 and 2016 presidential campaigns in Nigeria and the U.S.A. The study suggested that gender/sexual orientation recorded highest hate speeches of $10.7 \%$, while both racism and health recorded $7.1 \%$ in the U.S.A. In Nigeria, hate speeches recorded $10.7 \%$ on political affiliation, personality/trust and educational queries; Nigeria's hate speeches scored $7.1 \%$ on the bases of ethnicity and health and there was no hate speech that focuses on gender/sexual orientation. In America, hate speeches were found more among nominees. In the case of Nigeria, the party followers of both opposing groups recorded more hate speeches than the nominees. Both campaigns recorded equal hate speeches on personality/trust. Waya (2017) concluded that hate speech can be used as an intended or unintended instrument for political violence and hatred, and as such, politicians should avoid its deliberate use but concentrate more on critical issues that can bring about peaceful elections.

Sharndama (2017) critically analysed the inaugural speech of President Muhammadu Buhari, which was delivered shortly after his swearing into office on 29th May, 2015. In carrying out the analysis, the study adopted the Norman Fairclough's (1998) three dimensional analytical models. Following the model, the speech was subjected to description (text analysis), interpretation (processing/ analysis) and explanation (social practice and analysis). The results of the findings suggested that an inaugural speech is a revelation of plans and hopes in the new government. The speech analysed particularly revealed the ideologies/plans on which the new government headed by President Muhammadu Buhari intended to operate. The most important ones included good governance, strengthening international relations, foreign policies and democracy, insecurity, corruption, improved power supply, and the nation's economy.

The result of the review shows that a good number of studies on campaign and other political speeches have been carried out by different researchers (Miriti \& Christopher, 2016; Waya, 2017) using critical discourse analysis as theoretical framework especially Van Dijk's version of CDA. None among the reviewed works comparatively analysed the presidential campaign speech manifestos of Presidents Muhammadu Buhari and Donald Trump, using the cooperative principle. The present study, therefore, intends filling this conspicuous gap created in the study of linguistics.

\section{THEORETICAL FRAMEWORK}

\section{Paul Grice's Cooperative principles (CP)}

Since this study aims at a comparative analysis of the presidential campaign speeches of Presidents Muhammadu Buhari and Donald Trump, its theoretical framework is the cooperative principle. For Grice, people cooperate in the process of communication so as to reduce misunderstanding. As Grice (1975, p. 26) in Brennam, Kuhlen and Charoy (2018) states, "Make your conversational contribution in a way that it is required, at the stage it should occur, and by the accepted purpose or direction of the talk exchange in which it is engaged." This rule is what Grice refers to as 'Cooperative Principle (CP)'.

Davis (1998) paraphrases the CP as contributing what is required by the accepted purpose of a conversation. Grice asserts that the CP thus formulated expresses a truism about rational communication, and it is due to this truism that conversational implicatures can be calculated. More specifically, Grice (1975, p. 27) claims that the CP encompasses a set of conversational maxims, governing rational communication. Grice's original maxims include:

Quantity: Make your contribution as informative as is required. Do not make your contribution more informative than is required.

Quality: Do not say what you believe to be false. Do not say that for which you lack adequate evidence.

Relation: Be relevant.

Manner: Be perspicuous.

The theory of cooperative principle encompasses a set of conversational rules that reduce misunderstanding in the process of communication. The theory also allows one to assess individuals' speeches in terms of their truthfulness (maxim of quality). It is, on this note that the researchers find the theory a worthy framework for data analysis. To achieve a detailed analysis, this paper will analyse Presidents Muhammadu Buhari and Donald Trump's presidential campaign manifestos based on one of the maxims (Maxim of quality) put forward by Grice (1975, p. 27).

\section{RESEARCH METHODOLOGY}

The study adopts content analysis research design. Content analysis is the study of audio files or information which has been recorded in texts, media or physical items. For Zeng, Zhang and Wang (2019), it is a research design for studying documents and communication artifacts, which might be texts of various formats, pictures, audio or video. The 
choice of this research design is necessitated by the focus of this study, which is to investigate already recorded events; Nigeria and America's presidential election campaigns of 2015 and 2016 respectively.

The population of this study comprises all the political speeches of Presidents Muhammadu Buhari and Donald Trump but based on the impossibility of studying all the political speeches delivered by Presidents Muhammadu Buhari and Donald Trump, we selected their presidential campaign manifestos of 2015 and 2016 respectively. Considering the bulkiness of analysing all their campaign speech promises, the study chooses promises on security, job creation and health care. These campaign speech promises were purposively selected owing to the fact that they are the promises of the current presidents of Nigeria and the U.S.A. These campaign promises are, therefore, analysed based on the ongoing events in Nigeria and the U.S.A.

In an attempt to elicit the best data for the study, we employ the use of online sources where sample newspapers are made accessible. Also, other materials both online and handy, which inform the current states of Nigeria and the U.S.A. as it affects the campaign promises, are consulted.

The analysis of the two presidents' campaign promises on security, job creation and health care is based on the maxim of quality, one of the tenets of the Gricean (1975) Cooperative Principle. One excerpt from each subject is randomly selected from the two presidents' campaign manifestos of 2015 and 2016 respectively to reflect the position of the maxim of quality as a conversational rule. Therefore, a total of six excerpts are analysed in this study.

\section{ANALYSIS AND DiSCUSSIONS}

Three major subjects (security, job creation and healthcare) were extracted from the campaign speech manifestos of Presidents Muhammadu Buhari and Donald Drump made in 2015 and 2016 respectively. Thus, the analysis is structured into three parts. The first part analyses the two Presidents' campaign speech promises on security; the second examines their campaign speech promises on job creation; while the third analyses their promises on healthcare. Analysis here is based on the maxim of quality, one of the conversational maxims in Cooperative Principle (CP).

\section{A. Analyses of Presidents Muhammadu Buhari and Donald Trump's Presidential Campaign Speech Promises on Security}

The security of a nation should be the priority of every president. Both Presidents Muhammadu Buhari and Donald Trump have shown in their presidential manifestos that they have the interest of the citizens of Nigeria and America respectively at heart by promising them an all round security if elected into power. The maxim of quality seeks to find out how true a contribution is, and that is why it requires a speaker to contribute that which he/she can prove to be true.

To ascertain Buhari and Trump's speeches conformity to the maxim of quality, let us consider the following excerpts, as well as make reference to Nigeria and America's situation reports.

\section{Excerpt 1: Buhari}

...combat insurgencies, kidnapping, armed robbery, ethno-religious and communal clashes, nationwide. (https://www.vanguardngr.com/2015/05/what-buhari-promised nigerians)

In the above excerpt, Buhari had promised to combat insurgencies and kidnapping in Nigeria. A well-known insurgent group in Nigeria is the Boko Haram Terrorist Group. This group employs suicide bombing, organised attacks on police and military installations, and rural communities, etc. as tactics to fight for their religious belief of western education being corrupt. To confirm the President's faithfulness in fulfilling this promise, a look at table 1, featuring the timeline of Boko Haram attacks in Borno state (from May to August 2017), as found in Vanguard Online News of August 20th, 2017 is worthwhile. 
TABLE 1

TIMELINE OF BOKO HARAM ATTACKS IN BORNO STATE FROM MAY TO AUGUST, 2017

\begin{tabular}{|c|c|c|c|c|}
\hline Date & (3) & Number of people killed & $\begin{array}{l}\text { Number of people } \\
\text { injured }\end{array}$ & $\begin{array}{l}\text { Number of people } \\
\text { kidnapped }\end{array}$ \\
\hline $\begin{array}{l}\text { May } \\
13 \text { th }\end{array}$ & $\begin{array}{l}\text { Twin suicide attacks in the University of } \\
\text { Maiduguri (UNIMAID) }\end{array}$ & $\begin{array}{l}\text { Hundreds of UTME candidates and } \mathrm{Mr} \text {. } \\
\text { Daniel Musa, a security guard }\end{array}$ & - & - \\
\hline $\begin{array}{l}\text { May } \\
16^{\text {th }}\end{array}$ & Shawari and Mandari in Konduga LGA & Countless & - & - \\
\hline $\begin{array}{l}\text { May } \\
18^{\text {th }}\end{array}$ & $\begin{array}{l}\text { Three female suicide bombers attack } \\
\text { UNIMAID }\end{array}$ & Countless, including the 3 female bombers & - & - \\
\hline June $8^{\text {th }}$ & $\begin{array}{l}\text { Three suicide attacks in Jiddari/Polo } \\
\text { general area of Maiduguri metropolis }\end{array}$ & 13 & 24 & - \\
\hline $\begin{array}{l}\text { June } \\
19^{\text {th }}\end{array}$ & Kofa village attack & 23 & 11 & - \\
\hline $\begin{array}{l}\text { June } \\
20^{\text {th }}\end{array}$ & Maiduguri-Damboa-Biu road attack & Scores dead & & 14 \\
\hline $\begin{array}{l}\text { June } \\
25^{\text {th }}\end{array}$ & $\begin{array}{l}\text { UNIMAD and surrounding communities } \\
\text { of Kaleri, Muna Garage general area }\end{array}$ & 17 & - & - \\
\hline July $7^{\text {th }}$ & $\begin{array}{l}\text { Security operatives repel suicide attacks } \\
\text { on UNIMAID }\end{array}$ & 2 & - & - \\
\hline $\begin{array}{l}\text { July } \\
12^{\text {th }}\end{array}$ & Suicide attack in Molai Kura, Maiduguri & 23 & 23 & - \\
\hline $\begin{array}{l}\text { July } \\
16^{\text {th }}\end{array}$ & Maiduguri & 1 & 1 & - \\
\hline $\begin{array}{l}\text { July } \\
25^{\text {th }}\end{array}$ & Bornoyesu, Borno state & 40 & - & 3 \\
\hline $\begin{array}{l}\text { August } \\
1^{\text {st }}\end{array}$ & Mildu village, Adamawa state & 7 & Countless & - \\
\hline $\begin{array}{l}\text { August } \\
8^{\text {th }}\end{array}$ & $\begin{array}{l}\text { Baga in Kukwa LGA, Borno state } \\
\text { Duguri, Dabar-Wanzam }\end{array}$ & $\begin{array}{l}31 \\
31\end{array}$ & - & - \\
\hline
\end{tabular}

Source: Vanguard Online News of August 20th, 2017

Table 1 suggests that over 200 people were killed, more than 60 persons injured, and 17 people kidnapped within four months (May-August) in one state (Borno). If we have such outrageous result for a state, the safety of the entire Nigerians is not guaranteed.

From excerpt 1 also, the President promised to combat communal clashes nationwide. In Nigeria today, groups of Fulani cattle rearers are perceived to be the brains behind some communal clashes. These groups of men take their herds of cattle through bushes, farms, streets and major roads of Nigeria in the name of grazing. While feeding their cattle, they damage both lives and property.

Also, to ascertain the fullfilment of the maxim of quality by the President, the activities of the Fulani herdsmen from 2016 to 2017, which mark the President's first and second year in office, will be examined.

As found in www.vanguardngr.com, Senator Chukwuka Utazi of PDP, Enugu North, lamented over the gory massacre of the people of Ukpabi Nimbo Community in Uzo-Uwani Local Council of Enugu State, during the senate meeting held on April 28, 2016. While moving the motion, Sen. Utazi recounted the attacks of the herdsmen between 2016 and 2017, all in Buhari led government. The recounted attacks are summarised in table 2 below: 
TABLE 2

HERDSMEN ATTACKS FROM 2016 TO 2017

\begin{tabular}{|c|c|c|c|c|}
\hline Year & Date & Location & $\begin{array}{l}\text { Number of people } \\
\text { killed }\end{array}$ & $\begin{array}{l}\text { Number of } \\
\text { people injured }\end{array}$ \\
\hline 2016 & January 3rd & $\begin{array}{l}\text { Udeni Ruwa, Nasarawa state. } \\
\text { Agatu, Benue state }\end{array}$ & $\begin{array}{l}12-38 \\
45\end{array}$ & - \\
\hline 2016 & January 17 th & Gareji, Taraba state & 3 & - \\
\hline$"$ & January 23th & $\begin{array}{l}\text { Demsare, Wunamokoh, Dikajam and } \\
\text { Taboungo, Adamawa state }\end{array}$ & $30-60$ & \\
\hline , & February 7th & Tom Anyiin & 10 & - \\
\hline , & February 11 th & Abbi, Enugu state & 2 & - \\
\hline , & February 24th & Agatu, Benue state & $300-500$ & - \\
\hline , & February 28th & , & 9 & - \\
\hline , & March 7th & Mbaya-Tombo, Benue state & 20 & - \\
\hline , & March 17th & ," & 17 & - \\
\hline , & March 26th & Awgu, Enugu state & - & 76 \\
\hline , & April 3rd-7th & Ohali-Elu, Rivers state & 23 & - \\
\hline , & April 9th & Ilado, ondo state & 1 & 1 \\
\hline , & April 10th & $\begin{array}{l}\text { Angari, Dashole, Dori and Mesuwa, Taraba } \\
\text { state }\end{array}$ & $15-44$ & - \\
\hline , & April 18th & Moor & 18 & - \\
\hline , & April 20th & Agatu, Benue state & - & 11 \\
\hline , & April 25th & Nimbo, Enug state & 46 & - \\
\hline , & November 25th & Dungun $\mathrm{Mu}$ 'azu, Katsina state & 8 & - \\
\hline 2017 & January 4th & Abraka and Obianukwu, Delta state & 5 & - \\
\hline , & January 8th & Demsa, Adamawa state & 49 & - \\
\hline , & January 9th & Abraka and Obianukwu, Delta state & 5 & - \\
\hline ," & January 15 th & RafinGona and BCC Gbagyi, Niger state & 11 & - \\
\hline , & January 17th & Samaru Kataf, Kaduna state & 3 & 5 \\
\hline$"$ & January 24th & $\begin{array}{l}\text { Ipiga, Benue state } \\
\text { Gidan Waya, Kaduna state }\end{array}$ & $\begin{array}{c}15 \\
5\end{array}$ & - \\
\hline , & February 10th & Rukumawa Tsafe, Zamfara state & 8 & - \\
\hline ," & February 21st & Southern Kaduna & 21 & - \\
\hline ," & March 1st & Delta and Rivers & 3 & - \\
\hline , & March 2nd & Mbahimin, Benue state & 10 & - \\
\hline , & March 6th & Omumu, Delta state & 2 & - \\
\hline , & March 11th & Mkgovur, Benue state & 7 & - \\
\hline , & March 14th & Umuobasiukwu, Abia state & 1 & Several \\
\hline , & March 28th & Emuhu, Delta state & 3 & 6 \\
\hline ," & May 8th & Tse-Akaa, Benue state & 3 & - \\
\hline ," & May 10th & Abraka, Benue state & 1 & 3 \\
\hline ," & May 12th & Ossissa, Delta state & 7 & - \\
\hline , & May 13th & Logo Local Government, Benue state & 8 & - \\
\hline , & May 18th & Afam Uku, Rivers state & 2 & - \\
\hline
\end{tabular}

Source: Vanguard Online News of June 1, 2017

Table 2 above is only a summary of the attacks by herdsmen recounted by Senator Utazi but not limited to what the Senator has given out. This is to say that there could be more of these attacks in the remaining months of the year 2017 and in 2018. For 2018, Osai Ojigho, Nigeria's director of Amnesty International, on Monday, 29th January, 2018, claimed that clashes between herdsmen and farmers in Adamawa, Benue, Taraba, Ondo and Kaduna have resulted in 168 deaths in January 2018 alone (www.amnesty.ie). From the account of Salami (2018), in 2017, the clashes between nomadic herdsmen and local farmers resulted in at least 549 deaths and thousands displaced across Enugu, Benue, Taraba, Zamfara, Kaduna, Plateau, Nasarawa, Niger, Plateau, Cross Rivers, Adamawa, Katsina, Delta and Ekiti states, and the government is still not doing enough to protect communities from these violent clashes.

\section{Excerpt 2: Trump}

... as soon as I take office, I will ask Congress to repeal the defense sequester that limited the military's budget.

Strengthen the military so that it's so big and so strong and so great that nobody's going to mess with us.

(Source: https://www.chron.com)

In excerpt 2 above, President Donald Trump had promised to ask the America Congress to eliminate the defense sequester. Department of Defense (DoD) News recorded that on 30th January, 2018, Trump told a joint session of congress that a strong defense is necessary to deter adversaries and asked them to end the dangerous defense sequester. The defense sequester was later eliminated as part of omnibus appropriations legislation passed in early 2018 (Carroll, 2017). This implies the fullfilment of the maxim of quality.

Also in the excerpt, Trump promised to strengthen the military. Records from Johnson (2016) show that on 16th November, 2017, the Senate backed Trump's expanded vision for the military when lawmakers sent him a defense policy bill, authorising a significantly increased military budget. The budget, which was more than what Trump had initially proposed includes funding for new equipment and strengthened nuclear defense sequester. The maxim of quality is obeyed in this excerpt. 
Comparatively, Buhari promised to secure the territorial integrity of Nigeria and combat insurgencies, kidnapping, ethno-religious and communal clashes, but the data presented suggest that he has not lived up to his promise. He therefore flouted the maxim of quality. Trump's inability to construct an impenetrable physical wall, which he laid so much emphasis on results in the non-fullfilment of this maxim. He fulfilled it when the defense sequester he promised to eliminate as soon as he assumes office was eventually eliminated in early 2018, and when the Senate authorised a significantly increased military budget to fulfill his promise of expanding military investment.

\section{B. Analyses of Presidents Muhammadu Buhari and Donald Trump's Presidential Campaign Speech Promises on Job Creation}

\section{Excerpt 3: Buhari}

.... as at 1999 , Nigerian rate of unemployment stood at about $8 \%$, today it is estimated from official statistics to be close to $30 \%$. I will embark on vocational training, entrepreneurial and skills acquisition scheme for graduates along with the creation of Small Business Loan Guarantee Scheme to create at least 5 million new jobs by 2019.

(Source: https://www.abusidiqu.com)

To establish the fullfilment of the maxim of quality, which demands truth in whatever contribution made during conversations, the study consults the National Bureau of Statistics (NBS) on employment and unemployment rates in Nigeria.

Records from the National Bureau of Statistics (NBS) suggest that Nigeria's unemployment rate rose from $14.2 \%$ to $16.2 \%$ in the fourth quarter of 2016 and $18.8 \%$ in the third quarter of 2017 (www.sunnewsonline.com). It also notes that the country's labour population increased from 83.9 million in the second quarter to 85.1 million in the third quarter of 2017, a difference of 1.2 million in additional work force (www.ssjed.org). The NBS stated that the total number of people in full-time employment (at least 40 hours a week) declined from 52.7 million in the second quarter 2017 to 51.1 million in third quarters and the number of people with labour force who were unemployed or underemployed increased from 13.6 million and 17.7 million respectively in the second quarter 2017 to 15.9 million and 18.0 million in the third quarter 2017 (www.ssjcd.org).

In analysing the reports from NBS, it is obvious that not much jobs have been created in Nigeria from 2015 when Buhari assumed office to the end of 2017, his second year in office, although the President had promised Nigerians 5 million new jobs by the end of his tenure. Instead, the country recorded increase in her unemployment rate, which is a set-back to the country's economy. The study, therefore, concludes that Buhari in his campaign promises on job creation has flouted the maxim of quality.

\section{Excerpt 4: Trump}

...create at least 25 million jobs and "be the greatest job president that God ever created."

Bring back manufacturing jobs from China, Mexico, Japan and elsewhere. States that can expect a rush of jobs include Pennsylvania, North Carolina, Michigan, Ohio, Florida, New Hampshire, Iowa, Nevada, New York and Virginia.

Encourage manufacturers to build or grow factories in the United States with tax incentives.

(Source: https://www.traderboersenboard.de)

Bring back the steel industry to Pennsylvania and use American-made steel in all federal infrastructure projects.

Make the auto industry in Michigan bigger and better and stronger than ever before. Bring the coal industry back to life in the Appalachian Mountain region.

Require employers to recruit from the unemployment office.

(Source: https://www.cihconline.com)

To ascertain the fullfilment of the maxim of quality by Trump, let us consider the following report from www.factcheck.org, a project of the Annenberg public policy centre.

Employment- Total nonfarm employment grew by more than 3.2 million during Trump's first 17 months in office, according to the most recent figures available from the Bureau of Labour Statistics.

Having 3.2 million nonfarm jobs is quite an achievement, continuing from an unbroken chain of monthly gains in total employment that started in October 2010. But the average monthly gain under Trump is 189,000 jobs, which is nearly 13 percent below the monthly average of 217,000 during Obama's second term. At the current monthly rate, a total of just over 18 million jobs would be added over eight years. That is better than the 11.6 million added under Obama and the 16.1 million added under Ronald Reagan, but still below the 22.9 million added when Bill Clinton was president, and the population was smaller.

Unemployment- The unemployment rate, which was below the norm when Donald Trump became president, has continued to fall even lower, to the lowest point in 18 years. The rate was 4.8 percent when he was sworn in, and then fell to 3.8 percent in May before rising to 4.0 percent in June 2018. Before the U.S. midterm election, Trump created 250, 000 new jobs between October to November 2018, thereby making the unemployment rate in America drop to $3.7 \%$.

Job Openings- Another reason employment growth has slowed is a persistent shortage of workers. The number of unfilled job openings hit a new record of more than 6.8 million in April 2018. In March, for the first time on record, the number of job openings exceeded the number of unemployed people looking for work, which was under 6.6 million. In 
May, the number of job openings slipped back to 6.6 million. That is a gain of nearly 1.2 million job openings; a rise of nearly 21.9 percent since Trump took office.

Manufacturing Jobs- Manufacturing jobs increased rapidly under Trump. The number rose by 344,000 between Trump's inauguration and June. That followed a net decrease of 192,000 under Obama. The increase under Trump amounts to 2.8 percent, even faster than the 2.2 percent increase in overall employment.

Going by the above report from www.factcheck.org, there is no room to gainsay the fullfilment of the maxim of quality by the American President Donald Trump. If Trump is yet to complete his second year and has recorded such great feat, it means he will by all standards live up to his promise of being the "greatest job president" ever known.

Buhari did not fulfill this maxim since he was unable to create 5 million new jobs. Instead, the unemployment rate in Nigeria increased in his administration. Trump on the other hand fulfilled the maxim of quality by creating many job openings and reducing the unemployment rate in the U.S.A. as he promised.

\section{Analyses of Presidents Muhammadu Buhari and Donald Trump's Presidential Campaign Speech Promises on Healthcare}

\section{Excerpt 5: Buhari}

Create an Insurance Policy for our Journalists as the nation faces hard times and our Journalists face more dangers in the discharge of their investigative work, to educate Nigerians in their rights and responsibilities. Ban medical tourism by our politicians from May 29, 2015.

(Source: https://www.abusidiqu.com)

The People Democratic Party (PDP) presidential aspirant, Senator Rabiu Kwankwaso has this to say: "Now that medical tourism has become the first choice of our leaders, we will ensure that the current situation in clinics and hospitals is given radical reforms" (Shibayan, 2018). Judging from the above statement, it becomes obvious that up till 29th August, 2018 when this statement was made, Nigeria's leaders still travel abroad for medical care and treatments. What this suggests is that Buhari, after promising to ban "medical tourism" by politicians in Nigeria, has not in any way done anything to fulfill this promise.

The New York Times, an American newspaper based in New York City reported on 8th May, 2018 that Buhari's latest trip to the United Kingdom took place after three weeks of strike by healthcare professionals who are calling for better working conditions and more funding. New York Times, in reaction to the president's medical trip, reminds the general public that during Buhari's campaign, he promised to ban foreign "medical tourism". The American News Giant also notes that Nigerians see Buhari's actions on health care as hypocritical. In reacting to Buhari's trip, Adebayo and Busari (2018) from the Cable News Network (CNN), on Thursday, 10th May, 2018 reported that the President's trip to the United Kingdom (U.K.) to see his doctor has reignited speculations about the state of his health and ability to rule Africa's biggest country (Nigeria). Buhari's medical trips abroad have sparked intense debate among Nigerians on social media as many argued that funds spent on medical bills abroad could be used to develop the country's healthcare system, which is in dire straits (Adebayo \& Busari, 2018).

From the reports above, Buhari promised Nigerians to ban "medical tourism" by politicians, which himself is one, but did not live up to the promise. Not only did he fail to fulfill this promise, he has travelled about two to three times to U.K. to seek medical attention.

\section{Excerpt 6: Trump}

...completely repeal the Affordable Care Act and replace it with something terrific that is so much better, so much better, so much better. Americans will have great healthcare at a fraction of the costs.

(Source: https://www.chron.com/)

Trump had promised to repeal and replace Obama care. This law, according to www.bbc.com, is widely hated by Republicans, who say it imposes too many costs on business, with many describing it as a 'job killer'. The Affordable Care Act, as it is officially called is seen as an unwarranted intrusion into the affairs of private businesses and individuals. It seems this promise will not be fulfilled although the White House insists Trump has not given up. Information from www.washingtonpost.com shows that on 24th March 2017, Republicans withdrew the bill since it lacked support. This makes Paul Ryan, a member of the House of Assembly to say that Obama care remains the law of the land. On 4th May, a revised version of the bill was almost approved by the House, but on 28th July, the Senate rejected a variety of different repeal bills, thwarting the establishment of a conference committee and apparently killing the effort. The final effort to revive the repeal bill failed before 30th September, after which the Senate could no longer use a legislative procedure to pass a bill with just 51 votes (www.washingtonpost.com). In all, Trump's promise of completely repealing and replacing Obama care is unfulfilled, making the maxim of quality also unfulfilled.

Buhari made so many promises regarding health care improvement and development, but some of these promises were not fulfilled. Similarly, one of the promises Trump made to Americans was to knock down the regulatory walls between states for health insurance. Although Trump signed Executive Order 13813, which is intended to promote the sale of health insurance association plans across state line, but the fullfilment of this promise cannot be guaranteed in this study. On the other hand, Trump's promise to repeal and replace Obama care is considered unfulfilled because it has not been achieved. The maxim of quality is flouted here like we have in Buhari's promises.

\section{CONCLUSION}


Cooperative Principle is an essential analytical tool for non-dialogic/interpersonal interaction. It provides the researcher with the opportunity to assess or grade individual's speech to ascertain its compliance to conversational rules/maxims. Examining the extent to which promises are fulfilled can only be achieved using the maxim of quality, an aspect of cooperative principle. Language use has great power potentials to negatively or positively influence public opinion or belief. As such, electorates are advised not to base their judgments or assessments on the carefully constructed speeches delivered by the election candidates, but to use their discretions when casting votes and consider the background records and personal attributes of these candidates.

The inquiry into the nature of the presidential campaign speech promises of Presidents Muhammadu Buhari and Donald Trump has revealed their faithfulness. The study, therefore, recommends further researches in the area as this will make politicians, who are not out to work be on their toes, knowing that the truth in their speeches are verified.

\section{APPENDIX}

Full texts: Presidents Muhammadu Buhari and Donald Trump's speeches are accessible from https://www.vanguardngr.com/2015/05/what-buhari-promised-nigerians/ https://www.washingtonpost.com/people/jenna-johnson/ respectively.

\section{REFERENCES}

[1] Abusidiqu (2015). Buhari's 2015 campaign promised to Nigerians. Retrieved from https://www.abusidiqu.com/buhari-2015promises-to-nigerians-details/ (accessed 4/4/2017).

[2] Adebayo, B. \& Busari, S. (2018). Nigeria's President Buhari heads to UK for more medical treatments. Retrieved from https://edition.cnn.com/2018/05/08/africa/nigeria-buhari-medical-leave/index.html (accessed 10/10/2018).

[3] Andy, J. \& Ofori, E. A. (2020). A critical discourse analysis of the campaign speech of a Ghanaian opposition leader. Theory and Practice in Language Studies, 10(10), 1279-1287. Doi: http://dx.doi.org/10.17507/tpls.1010.14. www.academypublication.com (accessed 3/11/2020).

[4] Arnold, O. \& Porter, S. (2017). Can federal OSHA withstand the injury? The Trump administration's impact on workers' protection rules. Retrieved from https://www.cihconline.com (accessed 20/3/2018).

[5] BBC. (2019). Obamacare: Has Trump managed to kill off affordable care act? Retrieved from https://www.bbc.com/news/world-us-canada-24370967 (accessed 4/4/2019).

[6] Brennan, S. E, Kuhlen, A. K. \& Charoy, J. (2018). Discourse and dialogue. https://www.onlinelibrary.wiley.com (accessed 20/4/2019).

[7] Carroll, L. (2017). White house budget requests funding to end defense sequester. Retrieved from https://www.politifact.com/truth-o-meter/promises/trumpometer/promise/1371/end-defense-sequester/ (accessed 4/4/2018).

[8] Davis, W. A. (1998). Implicature: Intention, convention, and principle in the failure of Gricean theory. Cambridge: Cambridge University Press. https://onlinelibrary.wiley.com/doi/abs/10.1111/phc3.12003 (accessed 20/32018).

[9] Department of Defense (2018). Trump's Sequestration. https://dod.defense.gov/News/Article/Article/694480/sequestration-poses-biggest-threat-to-readiness-military-leaders-say/ (accessed 4/4/2018).

[10] Donella, M. (2010). A guide to American campaign language. https://www.sustainabilityinstitute.org/dhm_archive/search.php?display_articles=vn25//anguaged (accessed 2/6/2018).

[11] Dopes (n.d). Muhammadu Buhari Biography - Age, Family, Pictures \& Net Worth. Retrieved from https://www.360dopes.com/muhammadu-buhari-biography-age-family-pictures-net-worth/ (accesses 4/4/2018).

[12] Fandom (n.d). Donald Trump. https://wes-weasley.fandom.com/wiki/Donald_Trump (accessed 25/4/2017).

[13] Fairclough, N. (1998). Critical discourse analysis: The critical study of language. London: Longman.

[14] Grice, H. P. (1975). Logic and conversation. New York: Academic Press. https://www.onlinelibrary.wiley.com (accessed 20/3/2018).

[15] Ike-Nwafor, N. G. (2015). Critical discourse analysis of selected political campaign speeches of gubernatorial candidates in South-Western Nigeria 2007-2014. P.hd Dissertation, Department of English/Literary Studies, University of Nigeria, Nsukka.

[16] Jackson, B. (2018). Trump's numbers (second quarterly update). Retrieved from https://www.factcheck.org/2018/07/trumpsnumbers-second-quarterly-update/ (accessed 30/10/2018). Johnson (2016). Trump's campaign promises. Retrieved from https://www.washingtonpost.com/people/jenna-johnson/(accessed 20/3/2017).

[17] Lyons, J. (2008). Introduction to theoretical linguistics. Journal of Linguistics, 9(1), 101-113.

[18] Marama, N. (2017). Timeline of Boko Haram attacks in Borno since may 2017. Retrieved from https://www.vanguardngr.com/2017/08/timeline-boko-haram-attacks-borno-since-may-2017/ (accessed 25/11/2018).

[19] Miriti, M. K. \& Christopher, W. O. (2016). Figurative language in electoral campaign speeches: A critical discourse analysis approach. M.A Dissertation, Department of English and Linguistics, Kenyatta University. https://www.ijam.com (accessed 20/32018).

[20] New York Times (2018). Nigeria's president draws criticism for seeking medical care. Retrieved from https://www.nytimes.com/2018/05/08/world/africa/nigeria-president-buhari-health.html (accessed 10/10/2018).

[21] Open Election Data Initiative (n.d). Key election process categories: Election campaigns. https://www.openelectiondata.net/en/guide/key-categories/election-campaigns/ (accessed 20/3/2018).

[22] Salami, D. (2018). Buhari's govt habouring murderers - amnesty international. Retrieved from http://www.citypeopleonline.com/buharis-govt-habouring-murderers-amnesty-international/ (accessed 4/4/2018).

[23] Sharndama, E. C. (2017). Political discourse: A critical discourse analysis of President Muhammadu Buhari's inaugural speech. European-American Journals, 3, 9-21. https://www.eajournals.org/journals/european-journal-of-english-language-and- 
literature-studies-ejells/vol-3-issue-4september-2015/political-discourse-a-critical-discourse-analysis-of-presidentmuhammadu-buharis-inaugural-speech-2/ (accessed 20/3/2018).

[24] Shibayan, D. (2018). Kwankwaso: Medical tourism is first choice of our leaders- I offer positive change. Retrieved from https://www.thecable.ng/kwankwaso-medical-tourism-change (accessed 2/10/2018).

[25] Sun News (2019). Nigeria's rising unemployment figures. Retrieved from https://www.sunnewsonline.com/nigerias-risingunemployment-figures/ (accessed 5/3/2019).

[26] Umoru, H. (2017). Herdsmen attacks, another Boko Haram-senate. Retrieved from https://www.vanguardngr.com/2017/06/01/herdsmen-attacks/anotherboko-haram-senate/ (accessed 25/11/2018).

[27] Van Dijk, T. A. (2004). Text and context of parliamentary debates. In P. Bayley (Ed.), Cross-cultural perspective on parliamentary discourse (pp. 339-372). Amsterdam: Benjamins.

[28] Vanguard. (2015). What Buhari promised Nigerians. Retrieved from https://www.vanguardngr.com/2015/05/what-buharipromised-nigerians/ (accessed 20/3/2018).

[29] Waya, D. T. (2017). A comparative study of the patterns of hate speeches during the Nigeria 2015 and U.S.A. 2016 presidential campaigns. Ph.D Seminar, University of Nigeria, Nsukka.

[30] Wikipedia. (n.d). Political campaign. Retrieved from https://www.en.wikipedia.org/wiki/political_campaign (accessed 20/4/2017)

[31] Zeng, N., Zhang, B. H. \& Wang, Q. (2019). STEM fever: Science educators' opportunities and challenges. America: AIP Publishing.

Chioma J. Ikechukwu-Ibe had her Bachelor of Arts and Master of Arts Degrees in Linguistics at the University of Nigeria, Nsukka. Her major research interests are on sociolinguistics, discourse and pragmatics, and psycholinguistics. Chioma has written many inciting articles published in reputable journals and a member of recognised professional bodies. Mrs. Ikechukwu-Ibe is a researcher in the Department of Linguistics, Igbo and Other Nigerian Languages, University of Nigeria, Nsukka.

Sopuruchi C. Aboh obtained his Bachelor of Arts Degree and Master of Arts Degree in Linguistics at the University of Nigeria, Nsukka. Sopuruchi specialises in sociolinguistics and pragmatics. Mr. Aboh is a member of Pragmatics Association of Nigeria, Nigeria Ecolinguistics Association, and Nigerian Institute of Translators and Interpreters and lecturer in the Department of Linguistics, Igbo and Other Nigerian Languages, University of Nigeria, Nsukka.

Christopher U. Agbedo is a professor of linguistics and currently lecturing in the Department of Linguistics, Igbo and Other Nigerian Languages, University of Nigeria, Nsukka. He specialises in sociolinguistics, discourse and pragmatics, as well as psycholinguistics. Professor Agbedo is a member of many reputable professional bodies across the globe. 